\title{
Periodontally Compromised Teeth: to Retain or Replace with Implant
}

\author{
Madhuri Alankar Sawai* \\ Department of Dentistry, Jamia Millia Islamia, India
}

Submission: November 01, 2017; Published: November 10, 2017

*Corresponding author: Madhuri Alankar Sawai, Department of Dentistry, Jamia Millia Islamia, New Delhi, India, Email: msawai@jmi.ac.in

\section{Mini Review}

Periodontal disease is the most common form of oral destructive disease which eventually leads to the loss of tooth. It affects about $40-50 \%$ of the population worldwide. Its prevalence increases with increasing age. Hence, as the life span of an individual increases; there will be increased prevalence of periodontally compromised teeth.

In the beginning of the $20^{\text {th }}$ century, extracted teeth were replaced with dentures. But in the recent past they are increasing being replaced by implants. Although, osseointegrated implants were first introduced for the management of completely edentulous arches, [1] they are now being frequently used to restore partially edentulous jaws. In the recent years, there has been an increased surge for extraction of periodontally compromised teeth and replacement with implants. Many of these natural teeth could be treated and salvaged for the next couple of years, if proper treatment is instituted. Hence, to extract a periodontally compromised tooth and its subsequent replacement with implant, as opposed to its retention by means of comprehensive periodontal therapy is one of the most debatable and complex decision to make in daily clinical practice.

The current clinical evidence has positioned implants as one of the first choices for treatment for partially or fully edentulous patients and has influenced the decision to extract periodontitisaffected teeth, which in a number of cases may be treatable [2]. Most clinicians today are also considering early teeth extraction followed by replacement with implants more superior to the preservation and conservative treatments for periodontally compromised teeth. However, their impression regarding survival and further deterioration of periodontally compromised teeth is necessarily not based on scientific evidence.

Some researchers suggested that strategic extractions would prevent bone destruction in a potential implant site. However, such an approach is not justifiable as alveolar bone resorption cannot be completely controlled by alveolar ridge preservation techniques or immediate implant replacement.
The concept of early extraction of periodontally involved teeth and their replacement with dental implants is based on a perceived advantage of implants like unpredictability of tooth survival, better prognosis of implants supported restorations, better functioning than periodontally compromised teeth, improved esthetics and cost effective with increased patient satisfaction [3]. However, it is questionable to which extent these concepts are supported by the current evidence.

Whether to extract a tooth or retain is a complex decision based on multiple patient and site risk factors. The strategic role of the tooth in the dentition, its periodontal, endodontic and restorative condition determines this choice. Various factors should be considered during planning of dental implant placement. In posterior edentulous areas, occlusal loading, muscular activity, chewing cycle and force, etc. should be carefully assessed. Similarly, in anterior esthetic zones, the decision to conserve or extract an esthetically compromised tooth will depend on multiple factors like smile line, gingival biotype, bone quality and patient's expectations. Pleasing and predictable outcome of implant restorations in anterior areas can be achieved only when the tissue support provided by the adjacent natural teeth is preserved.

Patients with history of periodontal disease are always at a higher risk of reinfection. This applies to dental implants placed in such periodontitis prone cases. Thus patient's susceptibility must be an important decision making criteria for implant cases. The supportive periodontal therapy also should be vigorously implemented and an extended observation period after completion of periodontal therapy should strongly be advocated to identify re-infection areas. Till the time such factors are dealt with, an implant will be unsuccessful.

Systematic reviews report that conventional tooth supported fixed partial dentures have 10-year survival rates of $85-90 \%$. When tooth and implant supported prostheses were compared, they have similar survival rates. Hence, natural teeth 
with reduced periodontium can equally prove favourable in supporting a fixed partial denture when compared to implant supported prostheses.

The clinicians' dilemma of retaining/restoring a periodontally compromised tooth or replacing it with an implant should not be done as the only treatment option but should depend upon their personal experience, expertise in the field, access to tools, local factors along with the patient-related parameters. These factors together should guide the final decision making and the widespread extraction of periodontally compromised teeth in lieu of replacement with implants should be avoided until it is in favour of the patients' treatment.

\section{References}

1. Branemark PI, Hansson BO, Adell R, Breine U, Lindström J, et al. (1977) Osseointegrated implants in the treatment of the edentulous jaw. Experience from a 10-year period. Scand J Plast Reconstr Surg Suppl 16: 1-132.

2. Greenstein G, Greenstein B, Cavallaro J (2007) Prerequisite for treatment planning implant dentistry: periodontal prognostication of compromised teeth. Compend Contin Educ Dent 28(8): 436-446.

3. Donos N, Laurell L, Mardas N (2012) Hierarchical decisions on teeth vs. implants in the periodontitis susceptible patient: the modern dilemma. Periodontal 2000 59(1): 89-110.

Your next submission with Juniper Publishers
will reach you the below assets
- Quality Editorial service
- Swift Peer Review
- Reprints availability
- E-prints Service
- Manuscript Podcast for convenient understanding
- Global attainment for your research
- Manuscript accessibility in different formats
( Pdf, E-pub, Full Text, Audio)
- Unceasing customer service
Track the below URL for one-step submission
https://juniperpublishers.com/online-submission.php

